Vol 13, Issue 11, 2020

Online - 2455-3891
Print - 0974-2441

$\underline{\text { Research Article }}$

\title{
ANTI-OBESITY EFFECT OF CANNABIS SATIVA SEED FLOUR FROM KHLALFA OF TAOUNATE REGION (NORTHERN OF MOROCCO) IN HIGH CALORIC DIET-INDUCED OBESE MICE
}

\section{MOUNA BOUARFA ${ }^{1 *}$, ZOUHAIR SOUIRTI ${ }^{2}$, PIERFRANCESCO CERRUTI ${ }^{3}$, MAURIZIO AVELLA $^{4}$, ABDELLAH FARAH $^{5}$, DALILA BOUSTA ${ }^{1}$}

${ }^{1}$ Laboratory of Neuroendocrinology and Nutritional and Climatic Environment. Faculty of Sciences, Sidi Mohamed Ben Abdellah University, B.P. 1796, Atlas, Fez, Morocco. ${ }^{2}$ CHU Hassan II - Neurology - 30000 - Fez - Morocco. ${ }^{3}$ Institute for Polymers, Composites and Biomaterials (IPCB-CNR), Naples, Italy. ${ }^{4}$ Institute for Chemistry and Technology of Polymers (ICTP-CNR), Naples, Italy. ${ }^{5}$ Laboratory of Applied Organic Chemistry, Faculty of Sciences and Technology, Sidi Mohamed Ben Abdellah University, Fez, Morocco. Email: bouarfa.mouna@hotmail.com

Received: 04 August 2020, Revised and Accepted: 23 September 2020

ABSTRACT

Objective: The objective of the present study was to evaluate the anti-obesity activity of Cannabis sativa seed Flour (CSSF) on obese mice.

Methods: The experiment process was carried out in 8 weeks. In this time, three groups of animals were adopted: High caloric diet control group (HCD), group treated with $100 \mathrm{mg} / \mathrm{kg}$ of CSSF, group treated with $200 \mathrm{mg} / \mathrm{kg}$ of CSSF, and normal diet control group (ND). Then, the histopathological and biochemical parameters analysis has been realized at the end of the experiment.

Results: As a result, body weight gain, epididymal, and perirenal adipose tissue decreased in the CSSF (Cannabis sativa seed Flour) group in both doses (100 mg/kg and $200 \mathrm{mg} / \mathrm{kg}$ ) compared to the HCD. CSSF lowered serum glucose level elevated by HCD. For lipid profiles, total cholesterol (TC), HDL-cholesterol, LDL-cholesterol, and triglycerides (TG) significantly decreased in the CSSF group. The histopathological results of this study showed a regenerative effect of CSSF on the kidney and liver tissues.

Conclusion: It is concluded from the present study that CSSF can be used as a natural anti-obesity agent.

Keywords: Cannabis sativa seed flour, Anti-obesity, Mice, Kidney, Liver, Taounate, Kif, Khlalfa

(C) 2020 The Authors. Published by Innovare Academic Sciences Pvt Ltd. This is an open access article under the CC BY license (http://creativecommons. org/licenses/by/4. 0/) DOI: http://dx.doi.org/10.22159/ajpcr.2020.v13i11.39304

\section{INTRODUCTION}

Cannabis is a seasonal herbaceous plant that has the THC molecule responsible for its psychoactive effect. However, there are also other molecules with a large therapeutic effect spectrum, such as CBD, CBC, and CBN, all of which are released by secreted glandular structures found in the leaves and flowers. The plant has also a high content of seeds, which has a high nutritional value. The use of cannabis seeds as a source of food and medicine is very old and is documented by documents from China, which describe that cannabis leaves, seeds, and stalks have been found in tombs that date back to more than 4500 years [1,2] Cannabis seeds and cannabis meal are excellent sources of digestible protein. In addition, great importance has been given to the cannabis seed protein due to its exceptional content of sulfur-containing amino acids [3,4], methionine, and cysteine [5]. Cannabis seeds protein contain also arginine and lysine [6]. Edestin is the major protein of cannabis seeds, which accounts for about $60-80 \%$ of the total protein content, which can be used in the production of biodegradable and even edible food packaging [7]. Cannabis seeds are also free from gluten, which makes it a very important source of vegetable protein for people who suffer from coeliac disease [8]. In this study, we tried to know the role of cannabis seed flour in the treatment of obesity problem using the aqueous extract of this ingredient.

Obesity is a chronic problem that has to be addressed in various ways. According to the World Health Organization (WHO), "Obesity is characterized by abnormal or excessive accumulation of body fat that can be harmful to the health." This obesity can cause people who suffer from it, a psychological blockage that is going to be the beginning of an even higher weight, or that will prevent the person to decrease his body weight [9]. This situation is only one of several consequences.
Moroccan population has manifested a severe change in lifestyles, including dietary patterns and physical activity. Morocco, therefore, in regard to the developing countries is undergoing to the consequences of a deviation of the Mediterranean food model. The examination of the evolution of food consumption makes it possible to draw several conclusions, such as a reduction of the complex carbohydrates and an increase of the simple sugars (sucrose), a higher consumption of cereals, an increase in the consumption of proteins of animal origin, of lipids, a decrease in the intake of dietary fiber... as well as a regressing of physical activity [10].

The regulation of appetite is one of all lot of ways for treating obesity, and it has been studied for about 7 years ago [11]. There are many chemical drugs directed to the treatment of obesity, but most of them were withdrawn from pharmacies due to the serious side effects shown. Faced with this problem, the natural alternatives are still the best because of their few or non-existent side effects. In this regard, we decided to work on the anorexigenic effect of the Cannabis sativa seed flour after the extraction of the oily part. Compared to several plants that have shown a potential natural alternative for the treatment of some metabolic alterations related to the problem of obesity, (Rosmarinus officinalis, Citrus paradisi, Citrus limon, Aloe vera, Mucuna pruriens seeds, Punica granatum, and Cyperus rotundus,...) [12-15], the study on the Cannabis sativa seed flour in the treatment of this disease is the first.

\section{MATERIALS AND METHODS}

Preparation of cannabis sativa seed flour extract

Cannabis seeds have been collected in Khlalfa region (north of Taounate) from Kif cultivar identified and authenticated by Prof. H. Ouhammou in 
Cadi Ayyad University in Marrakech. The seeds were washed by hexane to clean them from the THC contamination. Then, after being made powder, they were dilapidated with hexane in a Soxhlet apparatus for 6 $\mathrm{h}$ to remove the seed oil, and the doses of $100 \mathrm{mg} / \mathrm{kg}$ and $200 \mathrm{mg} / \mathrm{kg}$ of CSSF were prepared.

\section{Animals}

Twenty-four male Wistar albino mice (17-20 g) were used. They were housed in controlled laboratory conditions under standardized light $\left(12: 12 \mathrm{~h}\right.$ light-dark cycle), temperature $\left(22 \pm 2^{\circ} \mathrm{C}\right)$ with free access to food and drinking. At the end of the experiment, animals were anesthetized by ketamine $(60 \mathrm{mg} / \mathrm{kg})$, through intraperitoneal injection, and the blood and organs (liver and kidney) samples were collected for biochemical parameter analysis and histopathological study in the laboratory of pharmacology in the faculty of sciences of Sidi Mohamed Ben Abdellah University in fez, Morocco.

The animals were divided into four groups with six animals each. The negative control group, the positive control group with hypercaloric diet (HCD) and two treated groups with CSSF $(100 \mathrm{mg} / \mathrm{kg}$ and $200 \mathrm{mg} / \mathrm{kg})$.

The procedures used in this study are in accordance with the internationally accepted principles for the care and use of laboratory animals. Approval from the ethics committee at the Faculty of Sciences, Fez, Morocco, was obtained.

\section{HCD-induced obesity}

Mice were fed an HCD ( $6 \mathrm{~g} /$ mouse/day) in a pellet form for the period of 6 weeks. HFD was purchased from Central Market in Fes center. Composition of HCD is shown in Table 1.

\section{Experimental design}

In this study, 24 male Wistar mice were used and divided into four groups of six mice each. Group I: Negative control, mice fed with normal laboratory diet for the period of 8 weeks. Group II: Obese control, mice fed with HCD (6g/mice/day) for the period of 8 weeks.

Table 1: Compositions of the HCD

\begin{tabular}{ll}
\hline Ingredients & Quantity (\%) \\
\hline Crude protein & 30 \\
Crude oils and fats & 11 \\
Crude ash & 8 \\
Raw fibers & 3 \\
Linoleic acid & 1.8 \\
Arachidonic acid & 0.1 \\
\hline
\end{tabular}

Group III: Received high caloric diet for three weeks, then treated with CSSF (100 mg/kg, bw) for 30 days.

Group IV: Received high caloric diet for three weeks, then treated with CSSF (200 mg/kg, bw) for 30 days. All the drugs were administered orally through a standard orogastric cannula (Fig. 1)

Every day animals were observed for the external appearance, shape, color, and distribution of hair and physical activity.

\section{Biochemical serum analysis}

In our study, the biochemical parameters were assayed on serum. All serum analysis was collected in heparin tubes for the determination of different biochemical parameters such as glucose, cholesterol, triglyceride (TG), high-density lipoprotein cholesterol (HDL-C) levels, and low-density lipoprotein cholesterol (LDL-C) levels. These analyses were done in Hassan II hospital in Fez, Morocco.

\section{Histological analysis}

At the end of the experiment, animals were sacrificed and liver and kidney tissues were collected and preserved in $10 \%$ formalin. Liver and kidney sections ( $5 \mu \mathrm{m}$ ) were acquired and stained by hematoxylineosin and viewed under light microscope for further parameters.

\section{Statistical analysis}

Data are expressed as the mean \pm SEM. The statistical significance of difference between the mean values for the treatment groups was analyzed by ANOVA followed by Tukey test using Graphpad Prism version 5.03. Values of $\mathrm{p}<0.05$ were considered significant.

\section{RESULTS}

\section{Body weight gain}

In the HCD group, body weight gain of mice was greater than the values for the ND. HCD supplemented with $100 \mathrm{mg} / \mathrm{kg}$ and $200 \mathrm{mg} / \mathrm{kg}$ of CSSF reduced body weight gain of the mice. However, there was no significant difference in body weight gain among the ND and CSSF treated groups (Fig. 2).

\section{Food intake}

The results showed that the treatment with CSSF decreased significantly the food intake when compared with HCD control group (Table 2).

\section{Epididymal and perirenal fats weight analysis}

The result showed that, both epididymal and perirenal adipose tissues were decreased in CSSF group compared with HCD control group (Fig. 3).

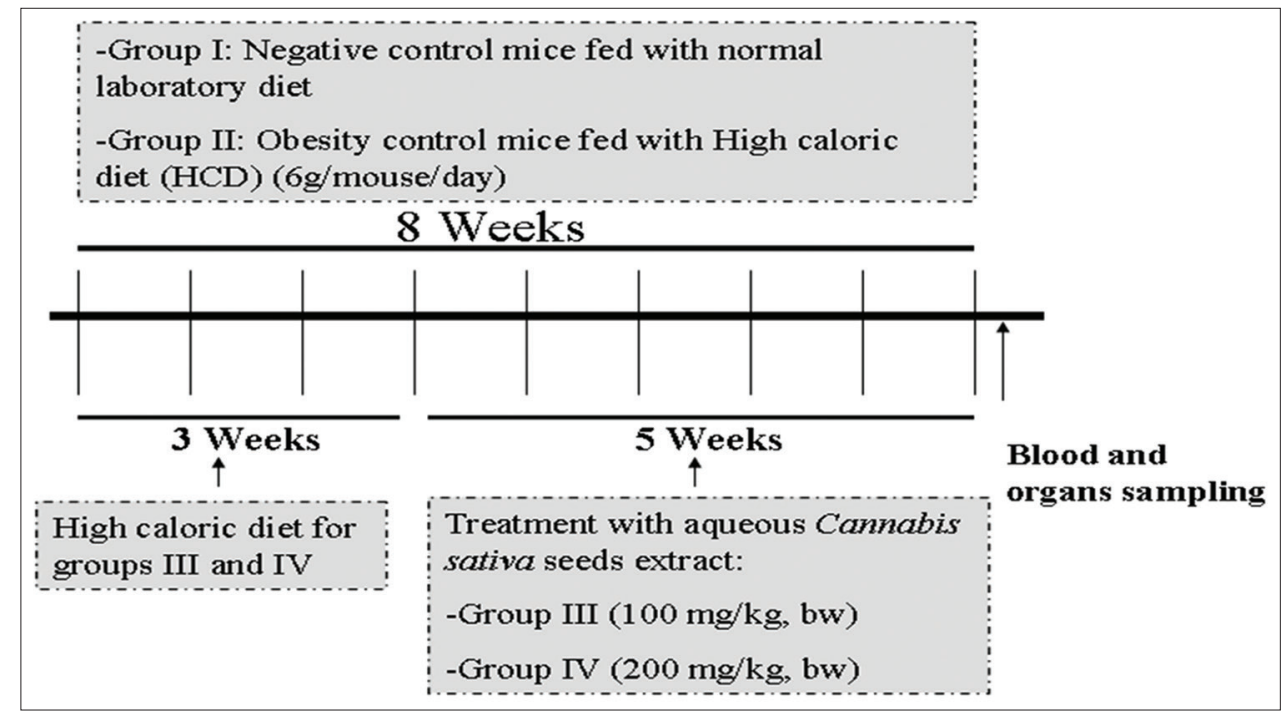

Fig. 1: Experimental design 


\section{Serum lipid levels}

Serum TC levels were significantly higher in HCD obese group compared to that of ND group and CSSF group ( $p<0.001)$. Levels of LDL, LDH, and triglycerides were significantly smaller in CSSF treated group $(\mathrm{p}<0.01)$, especially with the dose of $200 \mathrm{mg} / \mathrm{kg}$ compared with HCD obese group (Fig. 4).

\section{Serum glucose level}

Fig. 5 shows a significance decrease in serum glucose level $(p<0.05)$ for CSSF $(200 \mathrm{mg} / \mathrm{kg}$ ) compared to the other groups.

Table 2: Effect of Cannabis sativa seed flour $(100 \mathrm{mg} / \mathrm{kg}$ and $200 \mathrm{mg} / \mathrm{kg}$ ) on food intake for the experimental groups

\begin{tabular}{ll}
\hline Groups & Food intake (g) \\
\hline Normal diet (ND) & $17,45 \pm 0,08643$ \\
Obese control (HCD) & $17,46 \pm 0,1245$ \\
HCD + CSSF (100 mg/kg) & $16,96 \pm 0,02126^{*}$ \\
HCD + CSSF $(200 \mathrm{mg} / \mathrm{kg})$ & $16,79 \pm 0,05201^{* *}$ \\
\hline
\end{tabular}

${ }^{* *} \mathrm{p}<0.01,{ }^{*} \mathrm{p}<0.05$; Values are expressed as Mean \pm SEM ( $\mathrm{n}=6$ animals in each group) compared with obese control group (HCD)

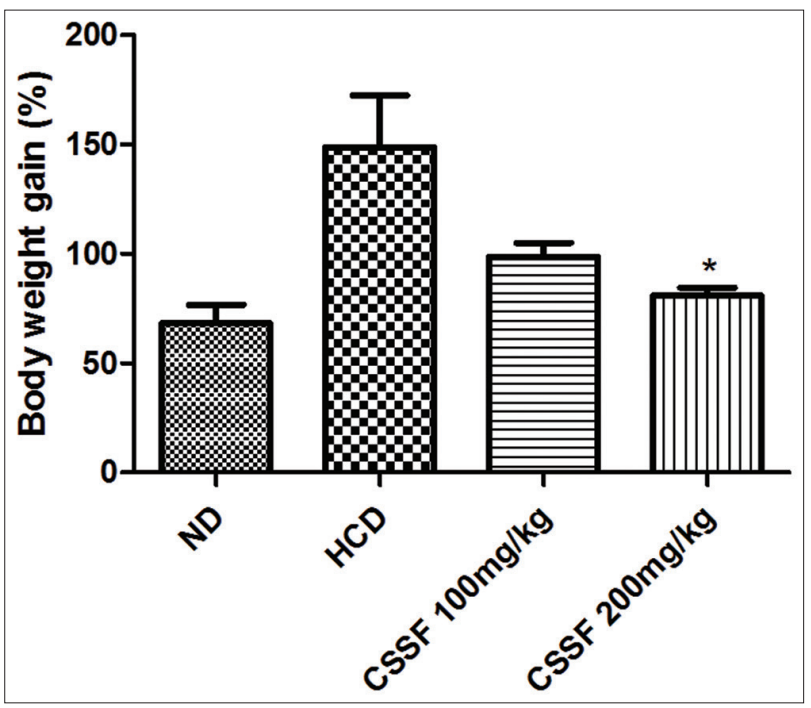

Fig. 2: Effect of Cannabis sativa seed flour $(100 \mathrm{mg} / \mathrm{kg}$ and $200 \mathrm{mg} / \mathrm{kg}$ ) on body weight gain for the experimental groups. ${ }^{*} \mathrm{p}<0.05$ compared with obese control group (HCD)
Histological analysis

The histological changes of liver and kidney of all four groups are shown in Figs. 6-13.

\section{DISCUSSION}

Obesity has been noted as a major public health problem in many countries, including Arab countries. It is associated with serious mortalities including hypercholesterolemia, high incidence of type 2 diabetes, cardiovascular disease, hyperlipidemia,... there are many antiobesity chemical drugs that manifested serious side effects such as heart attacks, strokes and severe liver injury, and for this reason the majority of them were withdrawn from the market [16]. In front of the adverse side effects of synthetic drugs, natural products are now preferably used due to their effectiveness in managing overweight and can be relatively more economical with little to no toxic side effects when compared with the synthetic ones [17]. The use of natural products not only offers advantages over chemical treatments in term of serious side-effects, but may give, in addition to the anti-obesity effect, also other health benefits, such as anti-diabetic and anti-hyperlipidemia activities.

The present study was carried out to investigate the anti-obesity effect of Cannabis sativa seed flour in HCD-induced obesity in Wistar mice. In this investigation, we found that the body weight was markedly reduced in the animal groups treated by CSSF compared with the HCD obese group. The decrease of body weight gain depends on a decrease in food intake. Indeed, we found that the treatment of CSSF suppressed the increases in epididymal and perirenal adipose tissue weights induced by an HCD.

Numerous experimental studies indicated that consumption of HFD leads to increased body weight and fat mass, induces alterations in carbohydrate and lipid metabolism, lead to insulin resistance $[18,19]$.

As a result, TG, TC, LDL, and LDH were significantly elevated in the HCD group compared with groups treated with CSSF. These laters showed a decrease in the levels of these parameters; which indicate a potential lipid lowering activity of the tested drug. Furthermore, it was shown that CSSF decrease blood glucose level, compared to the HCD group. This result may indicate insulin sensitivity improved in mice treated with CSSF. The anti-obesity effect of CSSF can be attributed to their protein and dietary fiber compounds. In this regard, protein is known to be more satiating than carbohydrate and is also associated with a greater diet-induced thermogenesis [20] this is why the intake of a high protein daily diet may help people lose weight and prevents weight gain rebound [21]. This ability of protein to lose weight may be related to the inducing of an increase in the level of plasma peptide tyrosine-tyrosine, which is a key

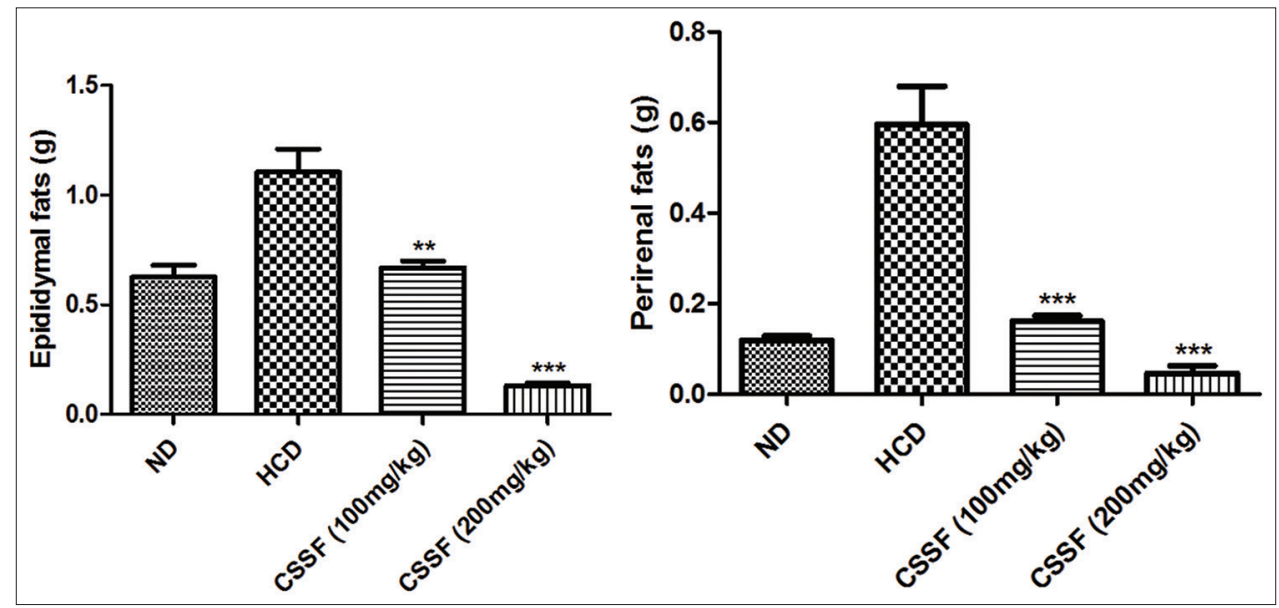

Fig. 3: Effect of Cannabis sativa seed flour $(100 \mathrm{mg} / \mathrm{kg}$ and $200 \mathrm{mg} / \mathrm{kg})$ on Epididymal and perirenal fats weight profile for experimental groups. ${ }^{* * *} \mathbf{p}<0.001,{ }^{* *} \mathbf{p}<0.01$; Values are expressed as Mean $\pm S E M$, compared with obese control group (HCD) 

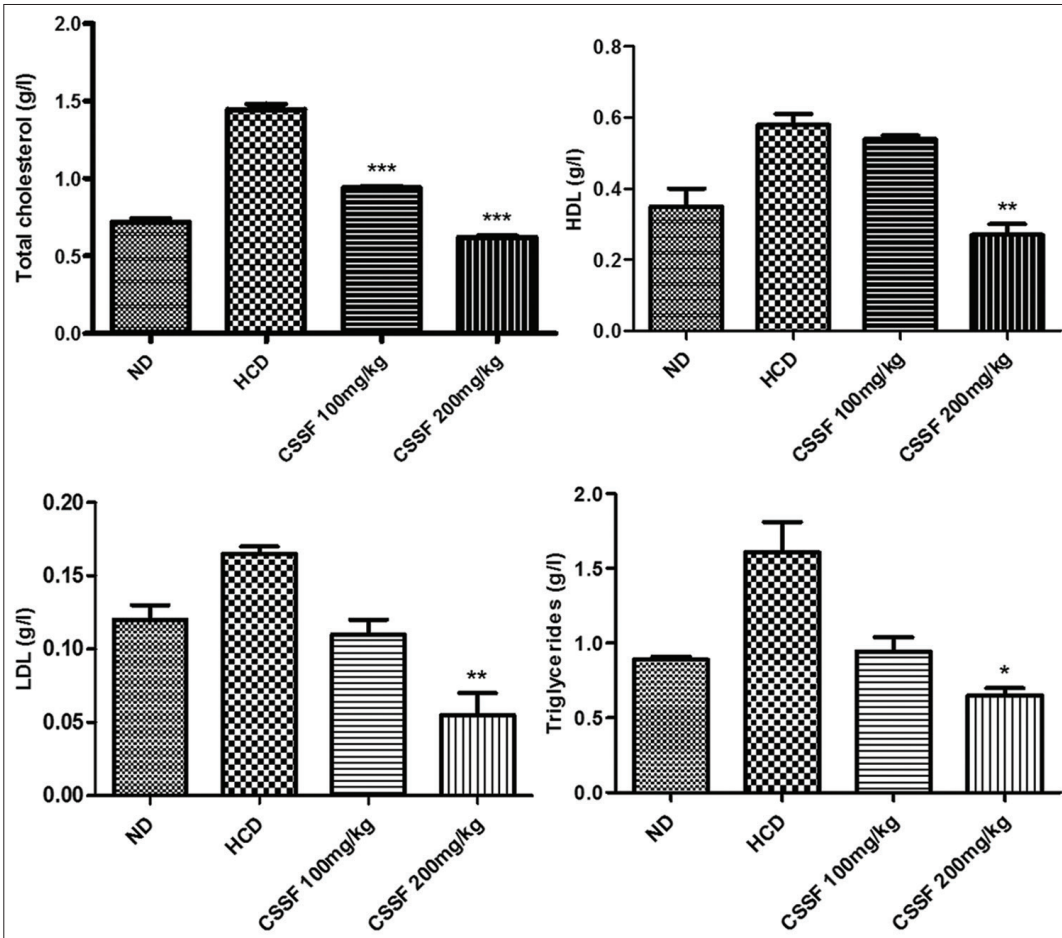

Fig. 4: Effect of Cannabis sativa seed flour $(100 \mathrm{mg} / \mathrm{kg}$ and $200 \mathrm{mg} / \mathrm{kg})$ on Lipid profile of the experimental groups. $* * * p<0.001, * * p<0.01$, ${ }^{*} p<0.05$; Values are expressed as Mean \pm SEM, compared with obese control group (HCD)

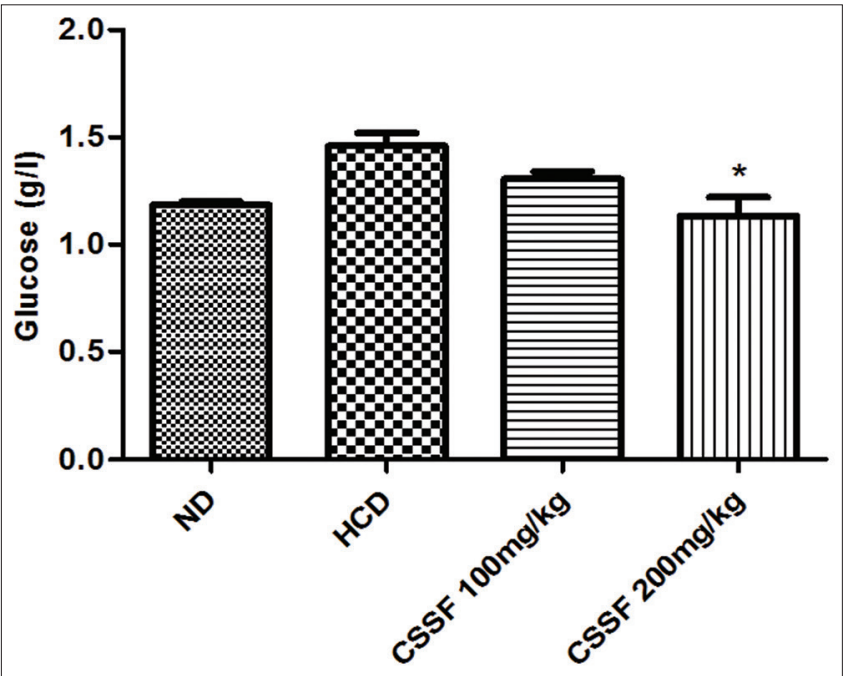

Fig. 5: Effect of Cannabis sativa seed flour $(100 \mathrm{mg} / \mathrm{kg}$ and $200 \mathrm{mg} / \mathrm{kg}$ ) on Glucose profile of the experimental groups. ${ }^{*} \mathrm{p}<0.05$; Values are expressed as Mean \pm SEM, compared with obese control group (HCD)

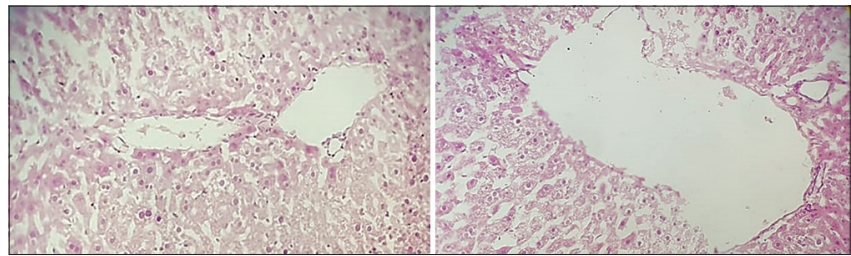

Fig. 6: Liver tissue of HCD group $\times 250$ showing a macro and micro steatosis (accumulation of triglycerides)

inhibitor of food intake in humans and rodents [22]. In addition, dietary fiber could also act an anti-obesity function by acting like a physiologic obstacle to lower energy intake by three mechanisms:

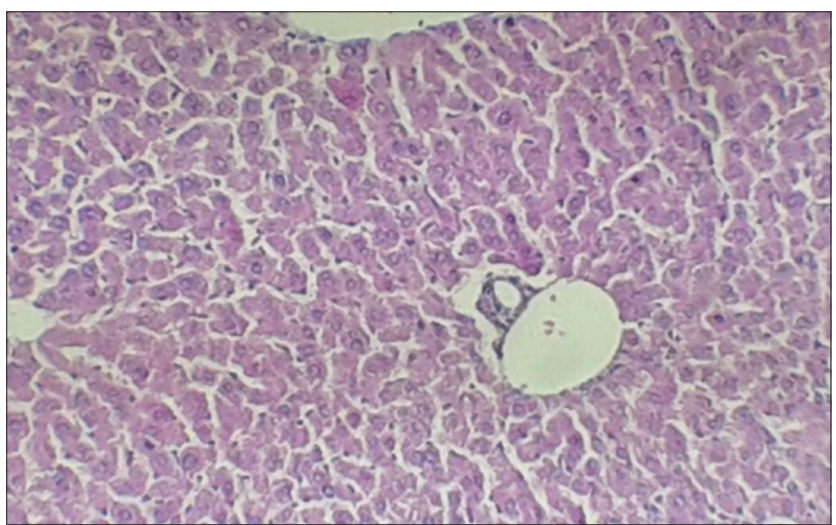

Fig. 7: Liver tissue of ND $\times 250$ showing normal histological structure

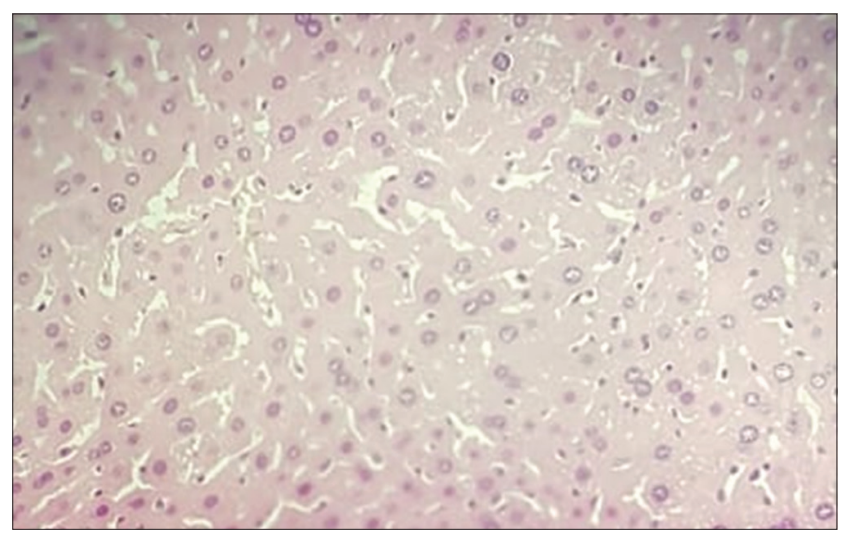

Fig. 8: Liver tissue of CSSF $100 \mathrm{mg} / \mathrm{kg} \times 250$ showing normal histological structure

(1) Displacement of other nutrients in the diet with dietary fiber;

(2) providing satiety and reducing appetite; and (3) inhibiting food 


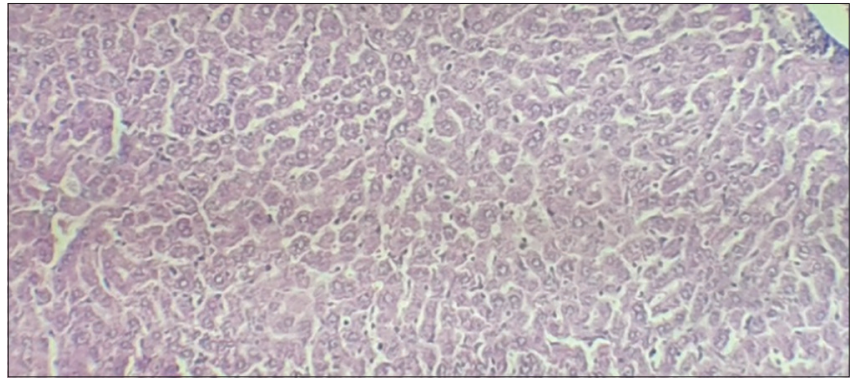

Fig. 9: Liver tissue of CSSF $200 \mathrm{mg} / \mathrm{kg} \times 250$ showing normal histological structure

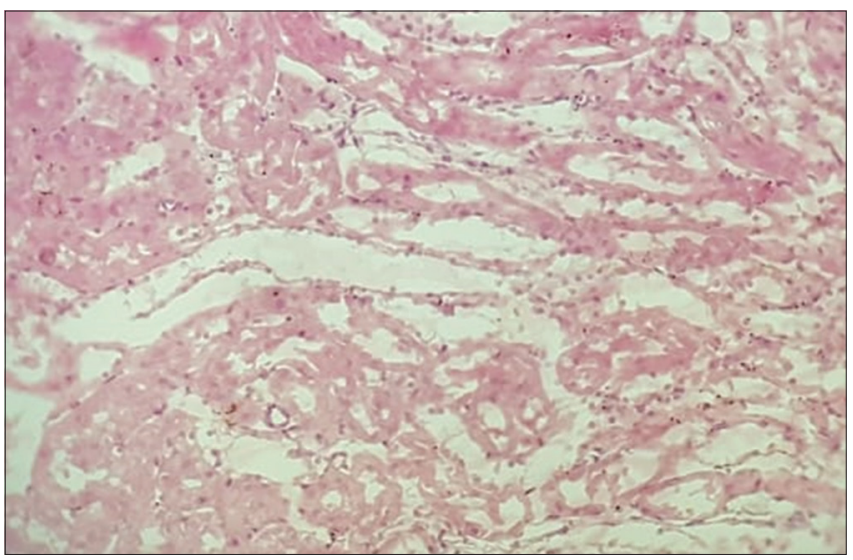

Fig. 10: Kidney tissue of HCD group $\times 250$ showing degenerative changes

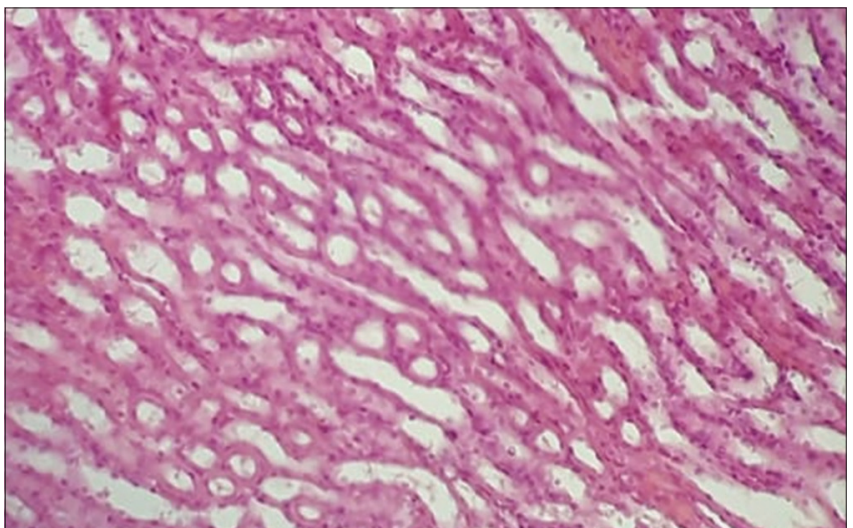

Fig. 11: Kidney tissue of ND $\times 250$ showing normal histological structure

absorption in the small intestine [23]. More studies have revealed that the beneficial physiological effects of dietary fiber are related to tow important physicochemical properties that are viscosity and fermentability [24]. An increase in viscosity may present a barrier to slow gastric emptying and delay nutrient absorption. As for the fermentability, dietary fiber could be a fermentable substrate for the colon microbiota, inducing an elevating in microbial mass and production of short chain fatty acids [16], which induce a reduction in body weight and stimulation of insulin sensitivity by stimulating oxidative metabolism in liver and adipose tissue.

According to our preliminary results, the anti-obesity effect possessing by CSSF may be attributed to the appetite suppression by protein and dietary fiber.

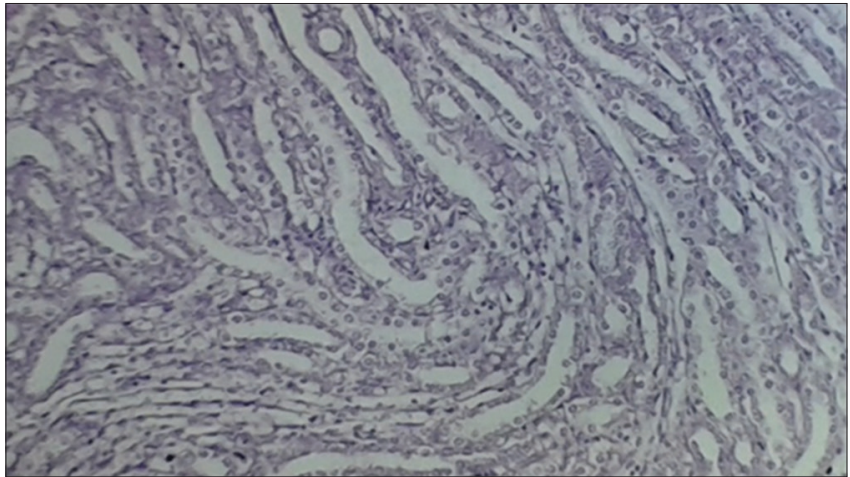

Fig. 12: Kidney tissue of CSSF $100 \mathrm{mg} / \mathrm{kg} \times 250$ showing normal histological structure

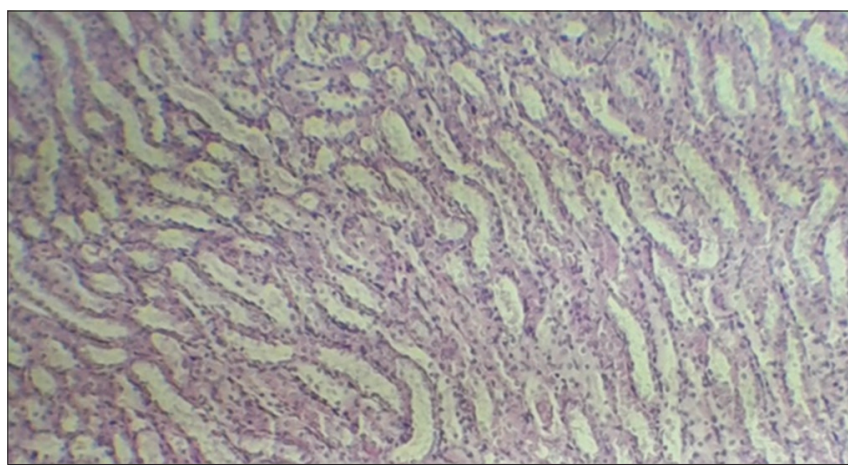

Fig. 13: Kidney tissue of CSSF $200 \mathrm{mg} / \mathrm{kg} \times 250$ showing normal histological structure

\section{CONCLUSION}

Our preliminary finding suggests that CSSF have a potential to reduce obesity through different biochemical and body parameters as compared to obese group. This result may be attributed to the appetite suppression practiced by our ingredient. Hence, to know exactly its mode of action in reducing obesity, more research could be carried in the future.

\section{ACKNOWLEDGMENT}

The authors are grateful to the support of the project H2020-MSCARISE-Marie Sklodowska-Curie Actions (MSCA) Research and Innovation Staff Exchange (RISE), Project Acronym: VAHVISTUS-Project Number: 734759 .

\section{AUTHORS' CONTRIBUTIONS}

All authors were contributed equally in this study

\section{CONFLICTS OF INTEREST}

The authors declare that there are no conflicts of interest.

\section{AUTHORS' FUNDING}

The authors received no specific funding for this work.

\section{REFERENCES}

1. de Padua LS, Bunyaprafatsara N, Lemmens RH. Plant Resources of South-East Asia: Medicinal and Poisonous Plants. Leiden: Backhuys Publishers; 1999. p. 167-75.

2. Jiang HE, Li X, Zhao YX, Ferguson DK, Hueber F, Bera S, et al. A new insight into Cannabis sativa (Cannabaceae) utilization from 2500-year-old Yanghai Tombs, Xinjiang, China. J Ethnopharmacol 2006;108:414-22. 
3. Callaway JC. Hempseed as a nutritional resource: An overview. Euphytica 2004;140:65-72.

4. Chuan-He T, Zi T, Xian-Sheng W, Xiao-Quan Y. Physicochemical and functional properties of hemp (Cannabis sativa L.) protein isolate. J Agric Food Chem 2006;54:8945-50.

5. Odani S, Odani S. Isolation and primary structure of a methionine and cystine-rich seed protein of Cannabis sativa L. Biosci Biotechnol Biochem 1998;62:650-4.

6. Callaway J, Pate D. Hempseed oil. In: Moreau R, Kamal-Eldin A, editors. Gourmet and Health-promoting Specialty Oils. $1^{\text {st }}$ ed. Urbana: AOCS Press; 2008. p. 215-36.

7. Shou-Wei Y, Chuan-He T, Qi-Biao W, Xiao-Quan Y. Properties of cast films from hemp (Cannabis sativa L.) and soy protein isolates. A comparative study. J Agric Food Chem 2007;55:7399-404.

8. Collin P. New diagnostic findings in coeliac disease. Ann Med 1999;31:399-405.

9. Claudine L. Guide Phyto-Minceur: Comment Maigrir à L'Aide des Plantes. $1^{\text {st }}$ ed. France: Dangles; 2012.

10. Ministère de la Santé, UNICEF. La Stratégie Nationale de la Nutrition 2011-2019. Maroc: Ministère de la Santé, UNICEF; 2011.

11. del Prete A, Iadevaia M, Loguercio C. The role of gut hormones in controlling the food intake. What is their role in emerging diseases? Endocrinol Nutr 2012;59:197-206.

12. Gamboa-Gómez CI, Rocha-Guzmán NE, Gallegos-Infante JA, MorenoJiménez MR, Vázquez-Cabral BD, González-Laredo RF. Plants with potential use on obesity and its complications. EXCLI J 2015;14:809-31.

13. Javid M, Archana P. Evaluation of the anti-obesity effect of aqueous extract of Mucuna pruriens seeds on rats. Int J Pharm Pharm Sci 2017;9:111-5.

14. Adnyana IK, Sukandar EY, Yuniarto A, Finna S. Anti-obesity effect of the pomegranate leaves ethanol extract (Punica granatum L.) in high fat diet induced mice. Int J Pharm Pharm Sci 2014;6:626-31.

15. Athesh K, Divakar M, Brindha P. Anti-obesity potential of Cyperus rotundus $\mathrm{L}$. aqueous tuber extract in rats fed on high-fat cafeteria diet. Asian J Pharm Clin Res 2014;7:88-92.

16. Nan-Nong S, Tsung-Yen W, Chi-Fai C. Natural dietary and herbal products in anti-obesity treatment. Molecules 2016;21:1351.

17. Chandrasekaran CV, Vijayalakshmi MA, Prakash K, Bansal VS, Meenakshi J, Amit A. Review article: Herbal approach for obesity management. Am J Plant Sci 2012;3:1003-14

18. Kaiyala KJ, Prigeon RL, Kahn SE, Woods SC, Porte DJ, Schwartz MW. Reduced beta-cell function contributes to impaired glucose tolerance in dogs made obese by high fat feeding. Am J Physiol Endocrinol Metab 1999;277:659-66.

19. Brown JL, Spicer MT, Spicer LJ. Effect of high-fat diet on body composition and hormone responses to glucose tolerance tests. Endocrine 2002;19:327-32.

20. Morell P, Fiszman S. Revisiting the role of protein-induced satiation and satiety. Food Hydrocoll 2017;68:199-210

21. Bendtsen LQ, Lorenzen JK, Bendsen NT, Rasmussen C, Astrup A. Effect of dairy proteins on appetite, energy expenditure, body weight, and composition: A review of the evidence from controlled clinical trials. Adv Nutr 2013;4:418-38.

22. van der Klaauw A, Keogh J, Henning E, Trowse V, Dhillo W, Ghatei M. High protein intake stimulates postprandial GLP1 and PYY release. Obesity (Silver Spring) 2013;21:1602-7.

23. Slavin JL. Dietary fiber and body weight. Nutrition 2005;21:411-8.

24. Astrup A, Kristensen M, Gregersen NT, Belza A, Lorenzen JK, Due A, et al. Can bioactive foods affect obesity? Ann NY Acad Sci 2010;1190:25-41. 